\title{
The Low Flow Assessment of Padma River in Bangladesh
}

\author{
Md. Abu Sayed, A. Akter* \\ Department of Civil Engineering, Chittagong University of Engineering \& Technology (CUET), Chittagong 4349, BANGLADESH \\ Parhatoli, Raozan, Chittagong - 4349, Bangladesh \\ ${ }^{*}$ Corresponding authors: aysha_akter@cuet.ac.bd
}

SUBMITTED 13 May 2021 REVISED 9 September 2021 ACCEPTED 19 September 2021

\begin{abstract}
Low flow or Environmental Flow (EF) assessment is vital to ensure the river and ecosystem remain healthy. Both natural and human interventions might alter a river. Therefore, this study presents EF requirements of the famous Hilsa breeding center in the Padma River, Bangladesh, by applying the Hydrologic Engineering Centers River Analysis System (HEC-RAS) for discharge and water surface levels simulations at different stations. The frequency analysis of 20 years of historical data, spanning 2000-2019, used the Log-Pearson Type III (LP-III) distribution method, while the one-dimensional unsteady flow simulation was performed for the last 10 years (i.e., 2012-2019). Subsequently, the HEC-RAS simulated water level values reasonably correlated with the field observations at four stations, namely Baruria Transit, Mawa, Tarpasha, Sureswar, with Coefficient of determination $R^{2}=0.86,0.83,0.92$, and 0.74 , alongside simulated minimum water surface levels of $1.57 \mathrm{~m}, 0.37 \mathrm{~m}, 0.30 \mathrm{~m}$, and $0.27 \mathrm{~m}$, respectively. Also, the Baruria Transit and Mawa had simulated flows that reasonably correlated with the field observations at $R^{2}=0.70$ and 0.61 , with a simulated minimum flow of $3849.51 \mathrm{~m}^{3} / \mathrm{s}$ and $3789.14 \mathrm{~m}^{3} / \mathrm{s}$, respectively. The minimum flow according to the frequency analysis was $4017 \mathrm{~m}^{3} / \mathrm{s}, 3685 \mathrm{~m}^{3} / \mathrm{s}, 3449 \mathrm{~m}^{3} / \mathrm{s}, 3229 \mathrm{~m}^{3} / \mathrm{s}$, and $3113 \mathrm{~m}^{3} / \mathrm{s}$ at Baruria Transit and $3304 \mathrm{~m}^{3} / \mathrm{s}, 2781 \mathrm{~m}^{3} / \mathrm{s}, 2438 \mathrm{~m}^{3} / \mathrm{s}, 2141 \mathrm{~m}^{3} / \mathrm{s}, 1992 \mathrm{~m}^{3} / \mathrm{s}$ at Mawa station in 5, 10, 20, 50 and 100 years return periods, respectively. This study overlooked to report the ongoing investigations into the water quality issues. Thus, this study is expected to guide the required $\mathrm{EF}$ quantity towards a healthy Hilsha fish habitat and surface water source for drinking purposes in this studied river. The stated method is also applicable to other similar rivers around the world.
\end{abstract}

KEYWORDS Environmental Flow; HEC-RAS; Log-Pearson Type-III; Hilsha Breeding, Return Period.

(c) The Author(s) 2022. This article is distributed under a Creative Commons Attribution-ShareAlike 4.0 International license.

\section{INTRODUCTION}

The harm to the entire ecosystem caused by 'low flow' below a certain level of a stream can be addressed and resolved by Environmental Flow (EF) assessments. Thus, EF describes the required quantity, quality, and timing of water flow to sustain the river ecosystem and maintain stakeholders' livelihood. In the late 1940s EF assessment methodologies were initiated in the United States of America, while the implementation occurred later in the 1970s. Besides the USA, methods for developing and implementing Environmental Flow Assessment (EFA) were executed around the 1980s or later. Generally, EFAs deal with the minimum flow required in any river flow regime without negative impacts on the river's ecosystem. Tharme (2003) found that most developed or advanced countries, particularly Australia and South Africa, were concerned with the development and application of EFAs. Based on the global literature on EFAs, Tharme (2003) recorded 207 different EFA methodologies used within 44 countries (Pusey and Arthington, 1991; Pusey et al., 1993; and Arthington \& Zalucki, 1998). Meanwhile, many EFA methods have been applied in Australia and occasionally modified based on the circumstances.

In Bangladesh, the applied EFA methods are mostly the Indicator of Hydraulic Alteration (IHA), Building Block Method (BBM), Mean Annual Flow (MAF), Flow Duration Curve (FDC), Range of Variability Approach (RVA), and the Tennant or Montana Method. Akter (2010) used the Indicator of Hydraulic Alteration (IHA) for analyzing hydrologic data and used RVA and BBM to assess the EF of the Ganges River after the construction of Farakka Barrage. The study also employed the Building Block Method (BBM) to estimate the fisheries and ecological demand, Sundarban's requirement, flushing flow, and 
morphological equilibrium (Akter, 2010). Jahid (2016) used the Flow Duration Exceedance Percentile (FDEP) Method for Kobadak River, while Akter and Ali (2012) used the Building Block Methodology (BBM) and Log-Pearson Type III (LPIII) for the Halada River. In addition, the MAF, FDC, and Constant Yield (CY) method were utilized for the Gorai and Turag Rivers (Moly et al., 2015; Rahman et al., 2013), while the Tennant, FDC, and Range of Variability Approach (RVA) methods were used for the Teesta River (Mullick et al., 2010). The Tennant or Montana Method, Flow Duration Curve (FDC) Analysis, Aquatic Base Flow, and RVA methods have also been applied on the North-West Zone of Bangladesh (Rahman et al., 2019). These techniques are often carried out on wetland, riparian vegetation, geomorphology, channel morphology, aquatic vibrates, freshwater, estuarine areas, water quality, and water-dependent wildlife. Hence, increasing awareness is necessary to continue the smooth ecological process, provide better services to the community, and maintain biodiversity (Smakhtin et al., 2004). There is currently no single method that can provide the solutions for all the EFA needs and requirements (Saha, 2007). However, "minimum low flow" is the key term to assess the EF of a regime, which is generally complex due to a shortage of flow monitoring data (Akter and Tanim, 2018). Hydraulic modeling also serves as a solution to determine the hydraulic parameters through the stream.

Meanwhile, Padma River plays an essential role for its diverse stakeholders, including a river ecosystem, drinking water supply, irrigation, industries, and navigation. It is also famous as the habitat of the Bangladeshi national fish, Hilsha. As shown in Figure 1, the Dhaka Water Supply and Sewerage Authority (DWASA) recently constructed a 450 million liters/day water treatment plant at Mawa to supply the drinking water (Khan and Uddin, 2019). However, the Farakka Barrage constructed in 1975 over River Ganges in West Bengal, India, has possibly reduced the Padma River's mean flows (Islam, 2006). This alteration has caused many problems to the river's ecosystem, including the loss of fish species, the drying of distributaries, saltwater water intrusion from the Bay of Bengal, and damage to the most extensive Sundarbans mangrove forests (Islam, 2006; Baten and Titumir, 2016). Also, the low flow has severely impacted the geomorphology, ecology, fish, and fisheries of Padma River, its branches, and surroundings (Rahman et al., 2003).

Padma river is well known for Hilsha breeding, as about $60 \%$ of this fish is available in Bangladesh. Hilsha contributes $11 \%$ of the total national production and 1\% of Gross Domestic Products (GDP) (Sunny et al., 2003). Although Hilsha fish can pass through comparatively lower depth (Average $10 \mathrm{~m}$ ) in the winter season, $20 \mathrm{~m}$ above water column is suitable for easy movement, migration, and pre-breeding congregation (Ahsan et al., 2014). Hence, reducing the Padma River flow restricts navigation, creates a disturbance in fish habitat, decreases soil moisture, lowers the groundwater table, and ultimately threatens the economic livelihood. The reduced freshwater flow also results in landward salinity intrusion, posing threats to the ecosystem.

Therefore, the main objective of this study is to assess the EF requirements of the Padma river using HEC-RAS to conduct intensive hydraulic modeling. The lowest discharge and water level at different return periods were also predicted using the Log-Pearson Type III (LPIII) distribution method.

\section{MATERIALS AND METHOD}

\subsection{Study Area}

Bangladesh has a highly dynamic river system with a comprehensive seasonal fluctuation in discharge, which peaks during the monsoon from July to September and is lowest from January to March. It comprises the Ganges River, which originates from the Gongotri Glacier and runs through India and Bangladesh. At the confluence with Jamuna River near Goalundo, this river is known as the Padma and runs approximately 120 $\mathrm{km}$ with the Meghna River near the Bay of Bengal (Sultana and Alam, 2016). As shown in Figure 1, the Padma River started from the Ganges-Jamuna 
confluence to the Padma-Meghna confluence. It has a straight, whole course toward the southeast and holds some great islands.

\subsection{Methodology}

A river analysis computer program, HEC-RAS, was used to estimate the hydraulic parameters of the Padma River and assess the EF requirements. Meanwhile, the determination of low flow frequency was conducted using the Log-Pearson Type III (LPIII) distribution. Figure 2 presents the adopted methodology in this study.

\subsection{Data Preparation}

The long-term monthly water level data were collected between 2000 and 2019 from the Bangladesh Water Development Board (BWDB) for four gauging stations, namely Baruria Transit, Mawa, Tarpasha, Sureswar, depicted in Figure 1. Also, the discharge data of Baruria Transit and Mawa during this period were assembled. The minimum discharges from the observed longterm monthly dataset were $2540 \mathrm{~m}^{3} / \mathrm{s}$ and 1817 $\mathrm{m}^{3} / \mathrm{s}$ at Baruria Transit and Mawa stations, while the minimum water levels were $1.48 \mathrm{~m}, 0.84 \mathrm{~m}$,
$0.39 \mathrm{~m}$, and $0.26 \mathrm{~m}$ at Baruria Transit, Mawa, Tarpasha, and Sureswar stations, respectively. Meanwhile, the lowest flow duration and water level were recorded between December and April each year in the datasets.

Figure 3 shows the measured data for the 14 Padma River cross-sections collected from the BWDB in 2019 and the river bed elevations acquired from the $30 \mathrm{~m}$ Digital Elevation Model (DEM) by the United States Geological Survey (USGS).

\subsection{Low Flow Frequency Analysis}

Log-Pearson Type III, the Gumbel distribution method, and lognormal distributions are the most used streamflow frequency analysis techniques. The Gumbel distribution method has been used for designing flood control developments in Bangladesh (Ferdows and Hossain 2005). Subsequently, the minimum extreme values were selected from the yearly datasets, and the frequency analysis was conducted using the LPIII distribution following US WRC (USGS, 2019) recommendation.

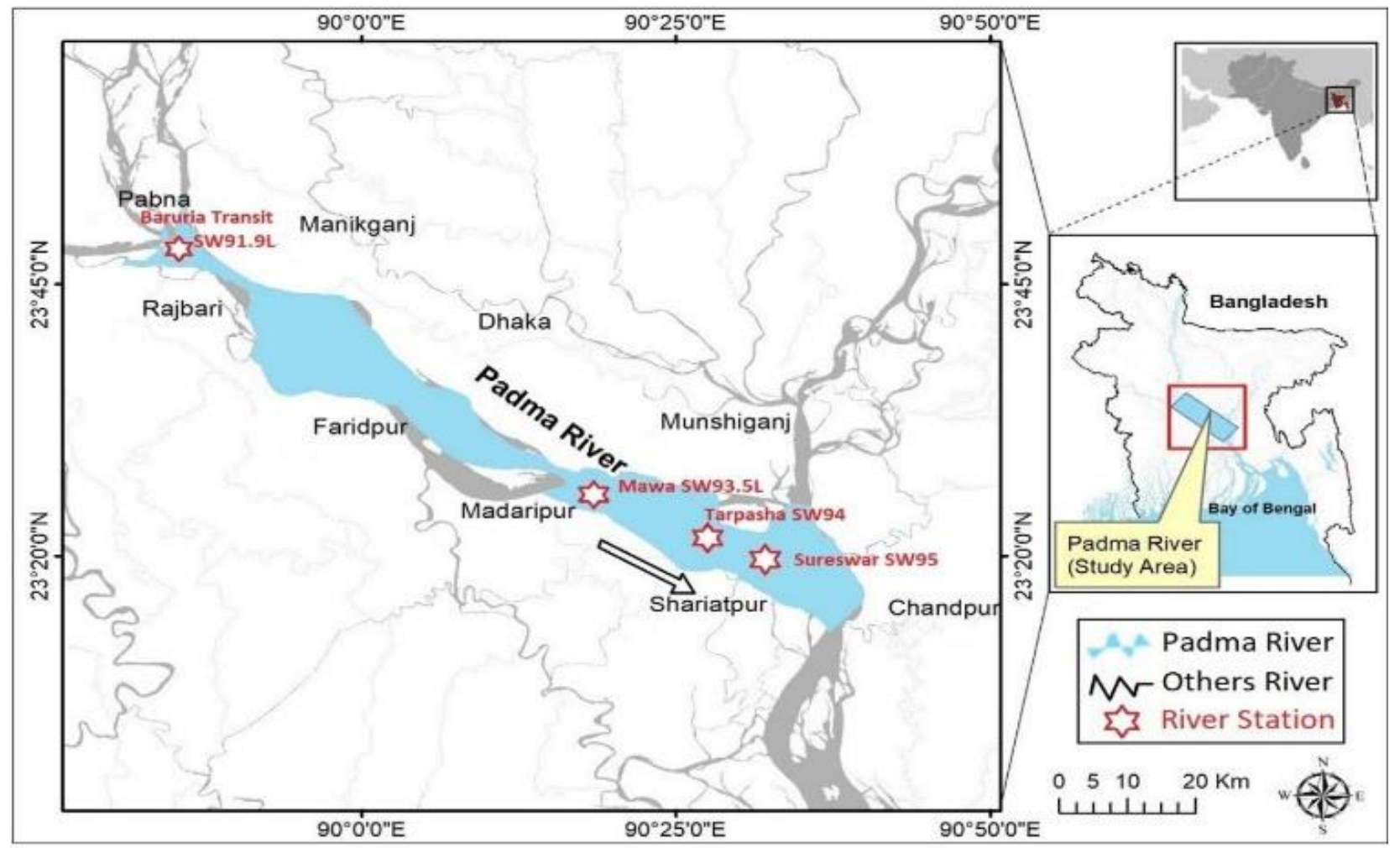

Figure 1. Location Map of the Study Area. 


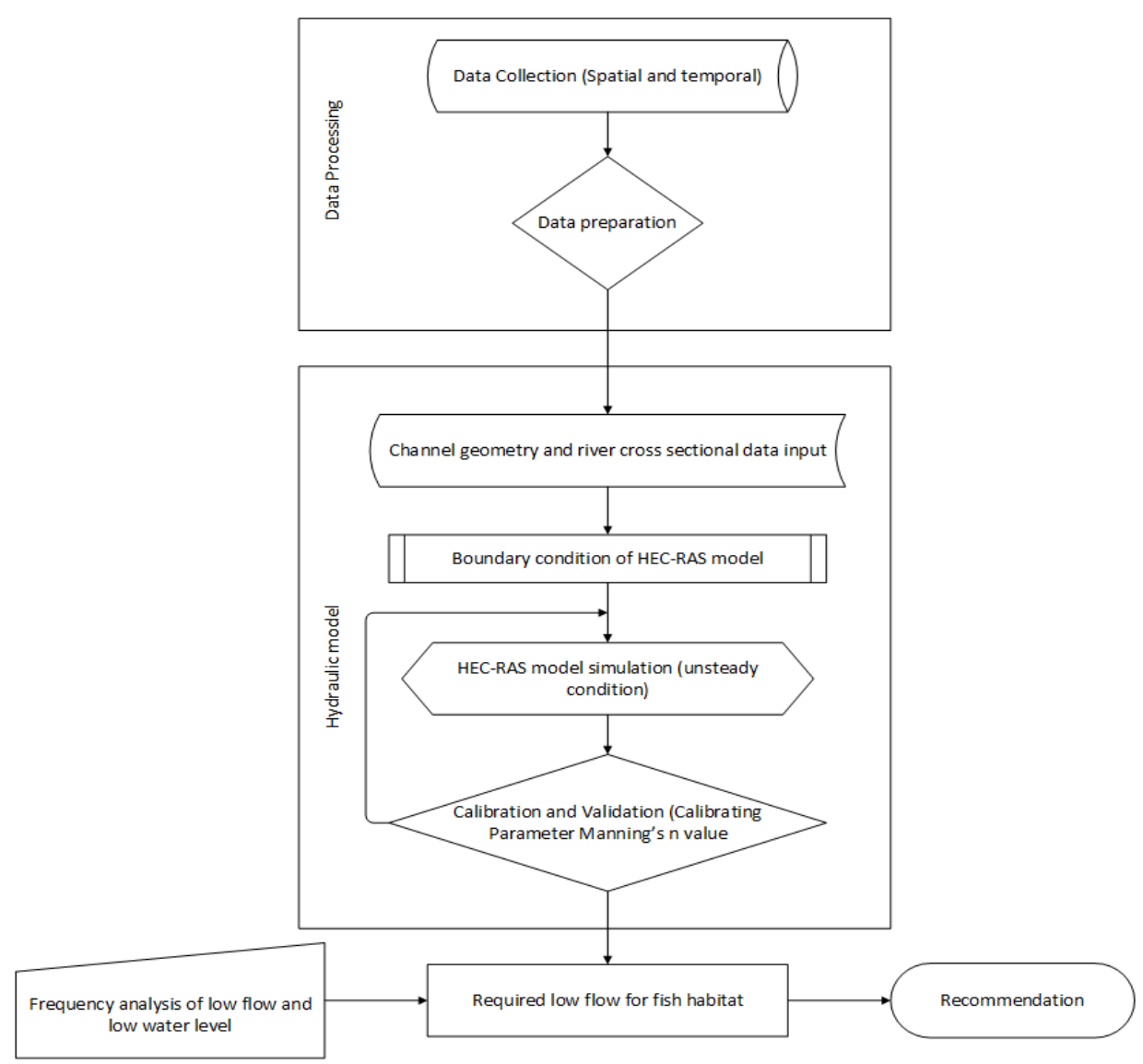

Figure 2. Flow chart of the adopted method.

The logarithms of the hydrological data, $y=\log x$, were used to calculate the mean, standard deviation, coefficient of skewness of the LPIII distribution. The frequency factor depends on the return period and coefficient of skewness and is equal to the standard normal variable when this coefficient is zero.

Here, $y_{m}$ is Average, $\mathrm{s}$ is Standard Deviation, $C_{s}$ is the coefficient of skewness, $K_{T}$ is Frequency Factor, $T$ is Return Period, $z$ is Standard normal variable

When $C_{s}$ is $0, K_{T}$ is approximated (Kite, 1977) as:

$K_{T}=z+\left(z^{2}-1\right) k+\frac{1}{3}\left(z^{3}-6 z\right) k^{2}-\left(z^{2}-\right.$

1) $k^{3}+z k^{4}+\frac{1}{3} k^{5}$

Where $k$ is $C_{s} / 6$ and $C_{s}$ are given by

$C_{s}=\frac{n \sum_{i=1}^{n}\left(y-y_{m}\right)^{3}}{(n-1)(n-2) s^{3}}$
And $s$ is given by

$\mathrm{s}=\left[\frac{1}{\mathrm{n}-1} \sum_{i=1}^{n}\left(y-y_{m}\right)^{2}\right]^{1 / 2}$

The value of $z$ corresponding to a non-exceedance probability of $1-p(p=1 / T)$ can be calculated by finding the value of an intermediate variable, $\mathrm{w}$ is

$w=\left[\ln \left(\frac{1}{(1-\mathrm{p})^{2}}\right)\right]^{1 / 2}(0<\mathrm{p} \leqslant 0.5)$

Then, calculating $z$ using the approximation:

$$
z=w-\frac{2.515517+0.802853 w+0.010328 w^{2}}{1+1.432788 w+0.189269 w^{2}+0.001308 w^{3}}
$$

When $\mathrm{p}>0.5,1-\mathrm{p}$ can replace $\mathrm{p}$ in equation (4), and the $z$ value obtained by equation (5) provides a '-ve' sign. The obtained error is lower than 0.00045 following Abramowitz and Stegun (Abramowitz, M. and Stegun, 1965). 


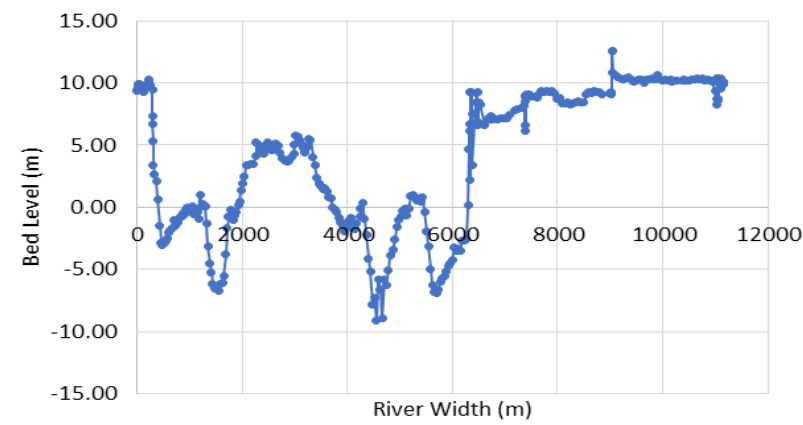

(a)

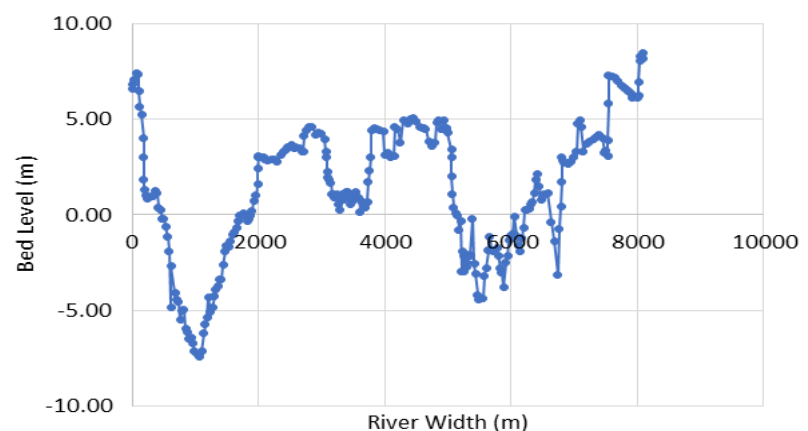

(c)

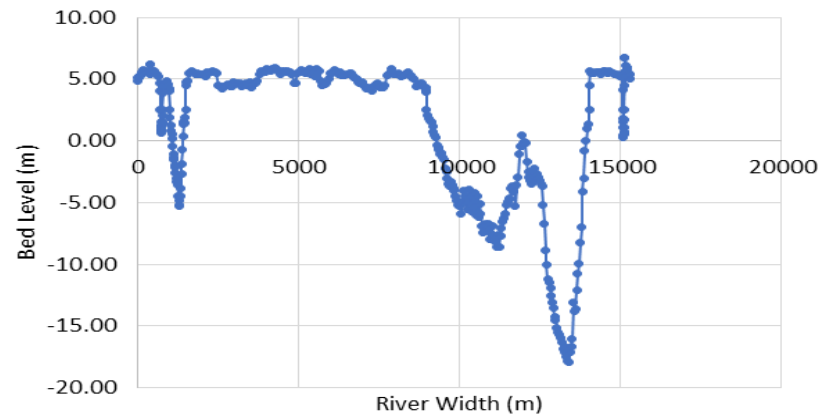

(e)

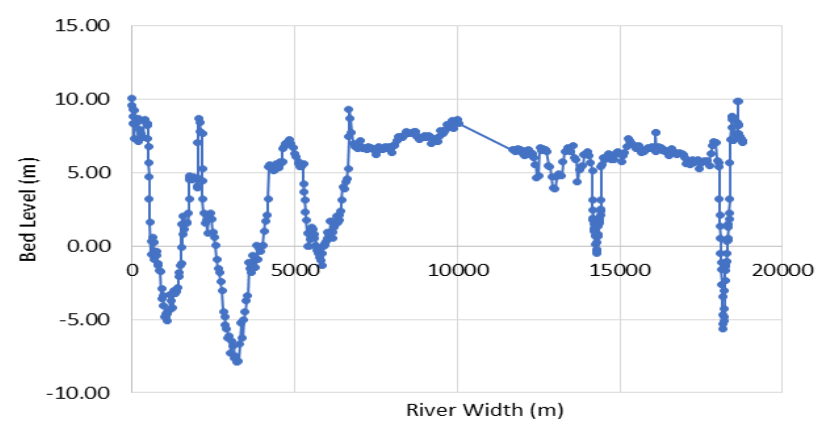

(b)

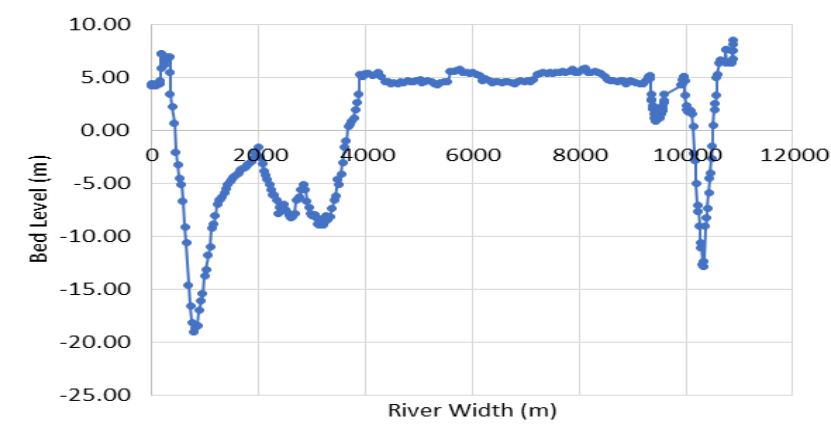

(d)

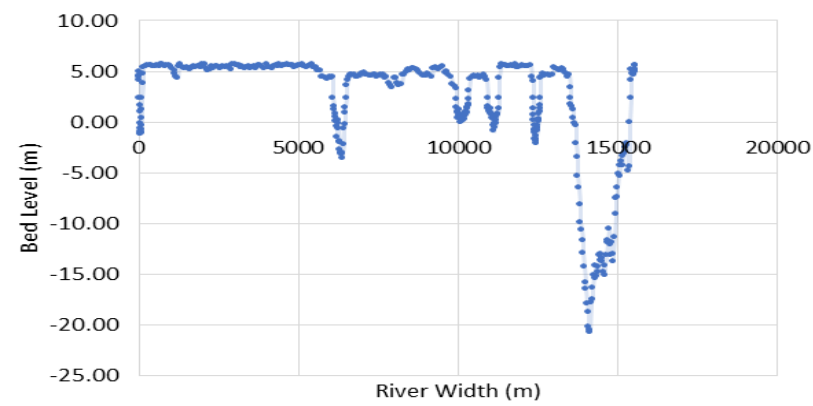

(f)

Figure 3. Riverbed level at each cross-section (marked on Figure 4) (a) Cross-section RMP8, (b) Cross-section RMP6, (c) Cross-section RMP4.1, (d) Cross-section RMP3, (e) Cross-section RMP1, (f) Cross-section RMP0.1

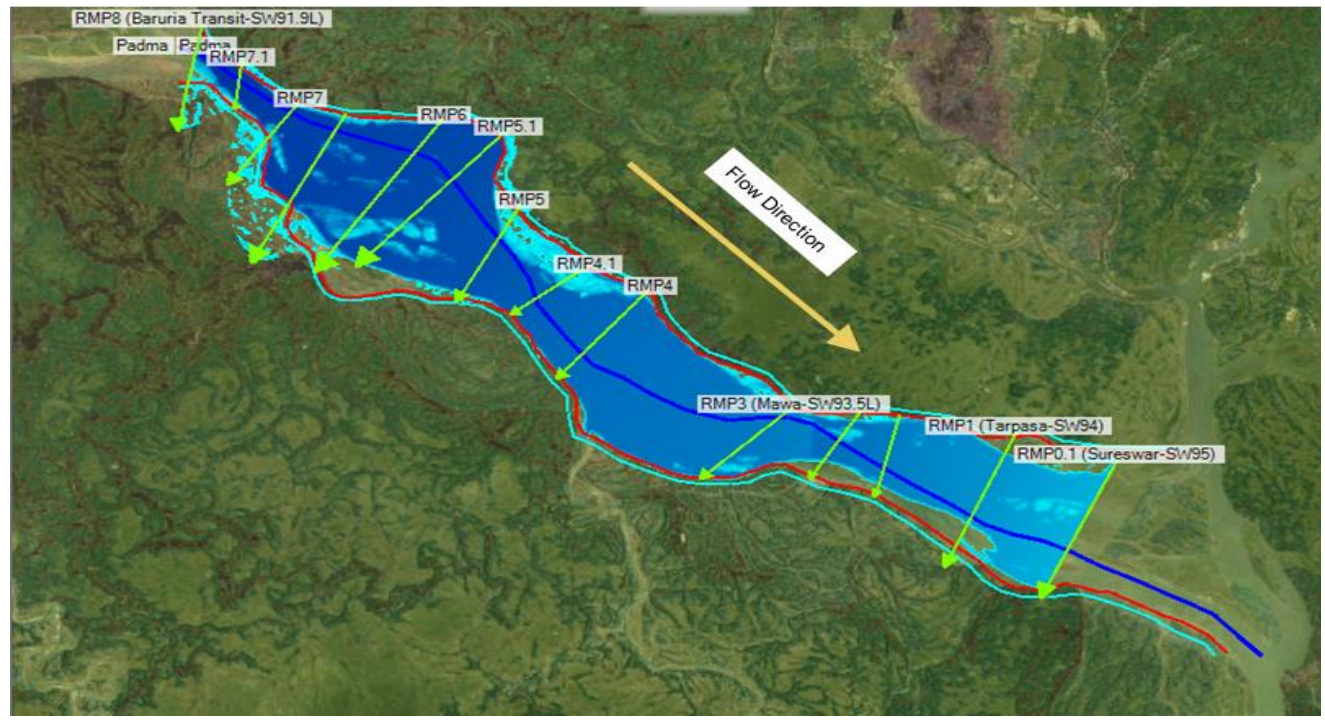

Figure 4. Padma River in the HEC-RAS Model. 


\section{MODEL SETUP}

\subsection{Input Parameters}

The Hydrologic Engineering Centre's River Analysis System (HEC-RAS, version 5.0.7) is a 1$\mathrm{D}$ hydraulic-flow model that requires hydraulic parameters for the stream channel geometry and water flow analysis. As shown in Figure 4, the stream comprises 14 cross-sections, and each consists of a left and right floodway and the main channel. The relevant input parameters are:

I. Geometric Data: The cross-section profiles consist of two components, i.e., the elevation data and properties. The cross-section has been located as GPS coordinates in the RAS Mapper and stored as geometric data. This RAS Mapper consists of and draws the stream centerline, cross-sectional cut lines, main channel bank lines, flow path lines, bridge/culverts, etc. In this study, the stream centerline and cross-sectional cut lines were taken as the fundamental data for the cross-section, while the main channel bank and flow path lines were the optional data. Then, the river bed elevation data at each cross-section has considered for subsequent editing.

II. DEM File: For the study, the 30m DEMs were acquired from the USGS.

III. Manning's roughness coefficients (n): The value of ' $\mathrm{n}$ ' for Padma River ranges from 0.04 to 0.015 from the low to bankfull stage (Neill, Hotopp, and Hunter, 2013). In this study, Manning's n value was 0.04 in the main channel and 0.015 at the left and right overbank.

IV. Following Brunner and CEIWR-HEC, the selected Contraction and Expansion coefficients were 0.1 and 0.3 , respectively (Brunner and CEIWR-HEC, 2016).

The model setup was based on two assumptions, (a) the constant energy head exists within the cross-section, and (b) the velocity vector is perpendicular to the cross-section. For the hydraulic computations in which the iterative calculation of the energy equation plays a vital role, the initial input consisted of channel geometry and river flow. Then, the rest of the analysis used the standard step method based on the secondary flow and the associated water surface elevation at each cross-section.

\subsection{Boundary Condition}

The Padma River flow simulation used the HECRAS unsteady flow analysis, as steady river flow conditions are unusual. The observed minimum flow hydrograph was an upstream boundary condition used at river station RMP8 (Baruria Transit SW91.9L). Furthermore, a low water level stage hydrograph measurement was employed as a downstream boundary condition at river station RMP0.1 (Sureswar SW95). The HEC-RAS model simulations of the unsteady state were computed at an hourly interval from Jan 2012 to Dec 2019.

\subsection{Statistical Analysis of the Model Outcome}

The hydrologic and hydraulic model performances were evaluated using a matrix of error statistics, namely Efficiency Index $(E I)$, Root Mean Square Error (RMSE), MPE (Mean Percentage Error) and MAPE (Mean Absolute Percentage Error), and $R^{2}$ (Coefficient of Determination) as follows:

$$
\begin{aligned}
& E I=1-\frac{\sum_{\mathrm{i}=1}^{N}\left(X_{i}-Y_{i}\right)^{2}}{\sum_{\mathrm{i}=1}^{N}\left(X_{i}-X_{i}^{m}\right)^{2}} \\
& R M S E=\sqrt{\frac{1}{N}\left(X_{i}-Y_{i}\right)^{2}} \\
& M P E=\frac{1}{N} \sum_{\mathrm{i}=1}^{N}\left(\frac{\left(X_{i}-Y_{i}\right)}{X_{i}}\right) \times 100 \\
& M A P E=\frac{1}{N} \sum_{\mathrm{i}=1}^{N}\left(\frac{A B S\left(X_{i}-Y_{i}\right)}{X_{i}}\right) \times 100 \\
& R^{2}=\frac{\left(\Sigma_{\mathrm{i}=1}^{N}\left(X_{i}-X_{i}^{m}\right)\left(Y_{i}-Y_{i}^{m}\right)\right)^{2}}{\Sigma_{\mathrm{i}=1}^{N}\left(X_{i}-X_{i}^{m}\right)^{2} \Sigma_{\mathrm{i}=1}^{N}\left(y_{i}-Y_{i}^{m}\right)^{2}}
\end{aligned}
$$

Here, the mean observed value, $X_{i}^{m}=\frac{1}{N} \sum_{i=1}^{N} X_{i}$ And mean predicted value, $Y_{i}^{m}=\frac{1}{N} \sum_{i=1}^{N} Y_{i}$

$N$ is the number of field observations. $Y i$ is the model Predicted value, and $X i$ is the observed value; a mean error below zero signifies that the model under-predicted the water level. 
The Efficiency Index $(E I)$ value ranges from $-\infty$ to 1 , while 1 is the best fit. An $E I$ value of approximately "0" refers to the model parameter following an accurate trend as an observed mean. Another statistical index is the coefficient of determination $\left(R^{2}\right)$, which shows the correlation between observed and simulated information.

\subsection{Frequency Analysis}

The frequency analysis showed the minimum water surface level (Reduced Level, RL) as $1.49 \mathrm{~m}$, $1.42 \mathrm{~m}, 1.37 \mathrm{~m}, 1.32 \mathrm{~m}, 1.30 \mathrm{~m}$ at Baruria Transit and $0.91 \mathrm{~m}, 0.87 \mathrm{~m}, 0.84 \mathrm{~m}, 0.82 \mathrm{~m}, 0.80 \mathrm{~m}$ at Mawa in 5, 10, 20, 50, and 100 years return periods, respectively. It also gave results of 0.67 $\mathrm{m}, 0.61 \mathrm{~m}, 0.57 \mathrm{~m}, 0.53 \mathrm{~m}, 0.51 \mathrm{~m}$ at Tarpasha, $0.22 \mathrm{~m}, 0.17 \mathrm{~m}, 0.14 \mathrm{~m}, 0.12 \mathrm{~m}, 0.11 \mathrm{~m}$ at Sureswar. The minimum flow was estimated as $4017 \mathrm{~m}^{3} / \mathrm{s}, 3685 \mathrm{~m}^{3} / \mathrm{s}, 3449 \mathrm{~m}^{3} / \mathrm{s}, 3229 \mathrm{~m}^{3} / \mathrm{s}, 3113$ $\mathrm{m}^{3} / \mathrm{s}$ at Baruria Transit and $3304 \mathrm{~m}^{3} / \mathrm{s}, 2781 \mathrm{~m}^{3} / \mathrm{s}$, $2438 \mathrm{~m}^{3} / \mathrm{s}, 2141 \mathrm{~m}^{3} / \mathrm{s}, 1992 \mathrm{~m}^{3} / \mathrm{s}$ at Mawa station in $5,10,20,50$, and 100 years return periods, respectively. Meanwhile, the water level and flow appeared at a minimum magnitude between December to April each year.

\section{MODEL CALIBRATION AND VALIDATION}

Model simulations were conducted monthly during 2012-2019, 2019 was selected as the calibrating year, and the findings were validated between 2016 to 2018. The calibrating parameter was Manning's n value (0.04), and the historical dataset was compared with the simulated / predicted water level data. As shown in Figure 5a, the minimum observed water level from 2012 to 2019 at river station RMP8 (Baruria Transit SW91.9L) was recorded as $1.48 \mathrm{~m}$ in March 2019, while the simulated water level was $1.57 \mathrm{~m}$ in April 2019. During the simulation period presented in Figure 5b, river station RMP3 (Mawa SW93.5L) had a minimum observed water level of $0.84 \mathrm{~m}$ in January 2019 , while the simulated water level was $0.37 \mathrm{~m}$ in March 2019. This period at the downstream river station recorded a minimum recorded observed water level of $0.74 \mathrm{~m}$ for RMP1 (Tarpasha SW94) in February 2013 and $0.26 \mathrm{~m}$ for RMP0.1 (Sureswar SW95) in February 2019. The simulated water levels at these two stations were
$0.30 \mathrm{~m}$ and $0.27 \mathrm{~m}$ in March 2019, respectively, as shown in Figures $5 \mathrm{c}$ and $\mathrm{d}$.

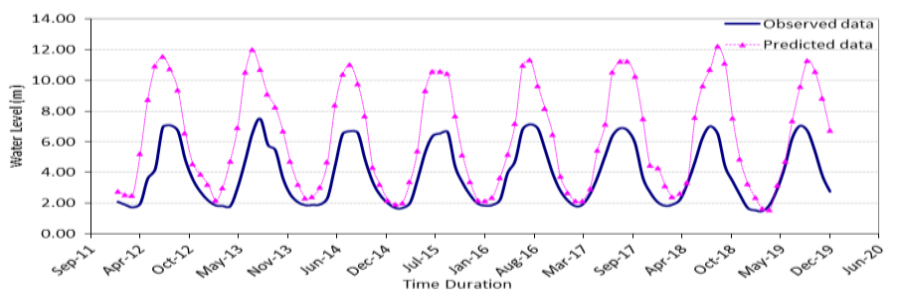

(a).

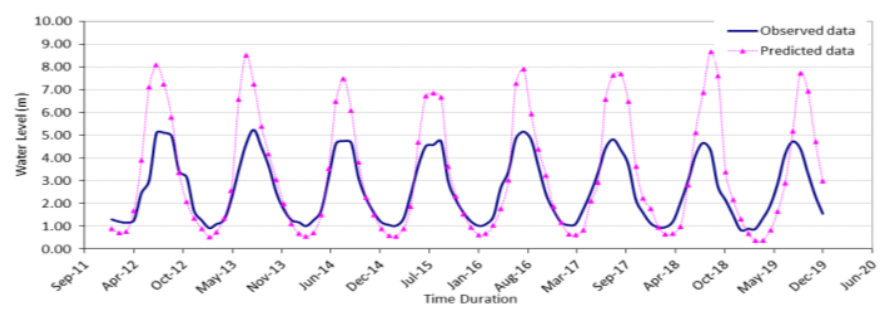

(b).

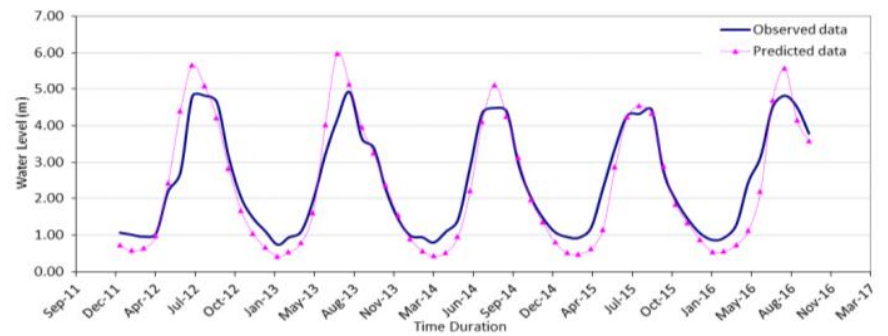

(c).

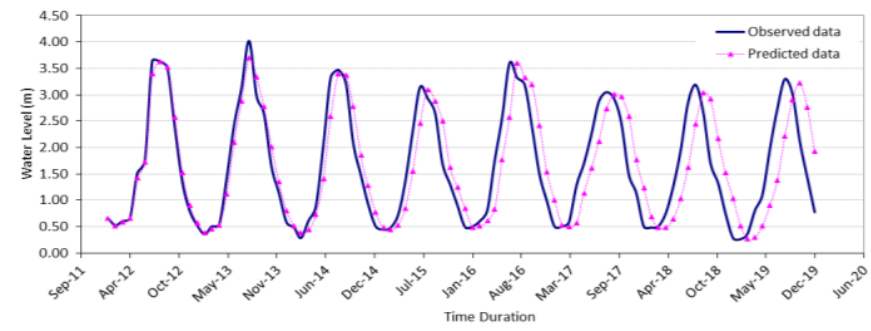

(d).

Figure 5. Simulated and observed water level comparisons at station (a) RMP8 (Baruria Transit SW91.9L). (b) RMP3 (Mawa SW93.5L). (c) RMP1 (Tarpasha SW94). (d) RMP0.1 (Sureswar SW95).

According to Figure 6a, the minimum observed flow from 2012 to 2019 at Baruria Transit was recorded at $2540 \mathrm{~m}^{3} / \mathrm{s}$ in March 2019, while the simulated minimum flow was $3849 \mathrm{~m}^{3} / \mathrm{s}$ in April 2019. During this period, the minimum observed flow was $1974 \mathrm{~m}^{3} / \mathrm{s}$ in February 2016, with a simulated minimum flow of $3789 \mathrm{~m}^{3} / \mathrm{s}$ in April 2019 at river station Mawa, as shown in Figure $6 \mathrm{~b}$. 


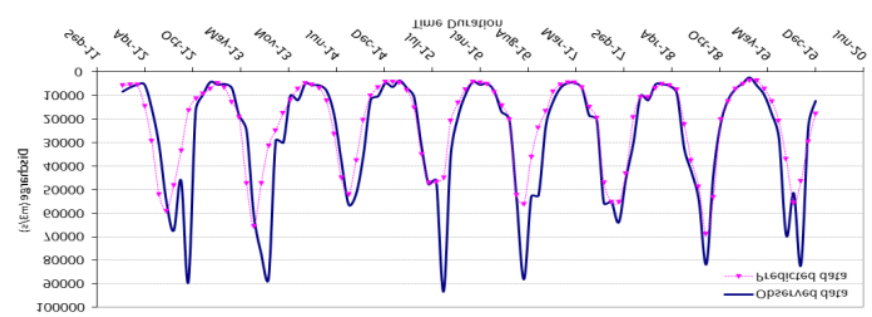

(a).

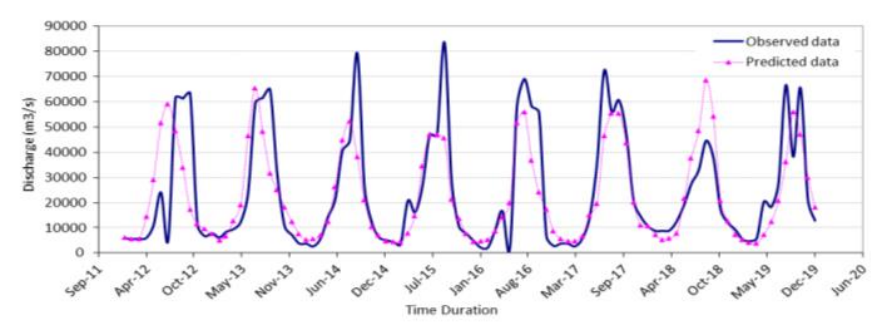

(b).

Figure 6. Simulated and observed flow comparisons at Station (a) RMP8 (Baruria Transit SW91.9L). (b) RMP3 (Mawa SW93.5L).

Table 1. Model Calibration Statistics

\begin{tabular}{|c|c|c|c|c|c|c|}
\hline \multirow{2}{*}{$\begin{array}{c}\text { Statistical } \\
\text { Parameters }\end{array}$} & \multicolumn{2}{|c|}{ Baruria Transit } & \multicolumn{2}{|c|}{ Mawa } & \multirow{2}{*}{$\begin{array}{c}\text { Tarpasha } \\
\text { Monthly Water } \\
\text { Level } \\
\end{array}$} & \multirow{2}{*}{$\begin{array}{c}\text { Sureswar } \\
\text { Monthly Water } \\
\text { Level }\end{array}$} \\
\hline & $\begin{array}{c}\text { Monthly } \\
\text { Water level }\end{array}$ & Monthly Flow & $\begin{array}{c}\text { Monthly } \\
\text { Water level }\end{array}$ & Monthly Flow & & \\
\hline EI & -1.12 & 0.69 & -0.66 & 0.63 & - & 0.26 \\
\hline RMSE & 2.91 & 14419.41 & 1.77 & 12729.99 & - & 0.90 \\
\hline MPE & -54.91 & 5.82 & -13.54 & 11.02 & - & -32.37 \\
\hline MAPE & 57.88 & 28.91 & 60.54 & 32.99 & - & 79.13 \\
\hline $\mathrm{R} 2$ & 0.74 & 0.78 & 0.58 & 0.66 & - & 0.39 \\
\hline
\end{tabular}

Table 2. Model Validation Statistics

\begin{tabular}{lrrrrrr}
\hline \multicolumn{1}{c}{$\begin{array}{c}\text { Statistical } \\
\text { Parameters }\end{array}$} & \multicolumn{2}{c}{$\begin{array}{c}\text { Baruria Transit } \\
\text { Monthly Water } \\
\text { level }\end{array}$} & $\begin{array}{c}\text { Monthly } \\
\text { Flow }\end{array}$ & $\begin{array}{c}\text { Monthly Water } \\
\text { level }\end{array}$ & $\begin{array}{c}\text { Monthly } \\
\text { Flow }\end{array}$ & \multicolumn{2}{c}{$\begin{array}{c}\text { Tarpasha } \\
\text { Monthly Water } \\
\text { Level }\end{array}$} & $\begin{array}{c}\text { Sureswar } \\
\text { Monthly Water } \\
\text { Level }\end{array}$ \\
\hline EI & -1.42 & 0.85 & -0.52 & 0.76 & 0.83 & 0.58 \\
RMSE & 2.94 & 8972.17 & 1.71 & 10670.27 & -17 & 0.66 \\
MPE & -53.15 & 10.41 & -16.85 & -19.56 & 21.76 & 25.75 \\
MAPE & 53.15 & 14.23 & 42.59 & 41.76 & 0.93 & 0.63 \\
R2 & 0.89 & 0.90 & 0.82 & 0.76 & & 0.62 \\
\hline
\end{tabular}

\subsection{Model Performance}

The low flow year, which was 2019, was selected as the calibration period. The statistical index in Table 1 shows that the $E I$ values against water levels at Baruria Transit and Mawa station were close to 0 , indicating the model parameter followed an accurate trend as an observed mean. Conversely, the $E I$ values against the flow at these stations were close to 1 , signifying that the model and observed parameters matched perfectly. The coefficient of determination $\left(R^{2}\right)$ at all the stations was close to 1 , denoting the reasonable correlation between the model and observed parameters. However, statistical parameter values were calculated at Tarpasha Station because of the unavailability of the observed values.From the validation conducted from 2016 to 2018, the statistical index in Table 2 shows that the $E I$ values at all the stations were close to 1 . Also, the coefficients of determination $\left(R^{2}\right)$ were close to 1 , and the $M P E$ value showed minor errors, indicating that the model and observed parameters matched.

\section{CONCLUSION}

This study aimed at assessing the EF of the Padma River using with HEC-RAS computer program HEC-RAS and low flow frequency analysis. Although fish, especially Hilsha, can pass through comparatively lower depth at a $10 \mathrm{~m}$ average in the winter season, $20 \mathrm{~m}$ above water depth is suitable for easy movement, migration, and prebreeding congregation. Hence, this $20 \mathrm{~m}$ water or channel depth maintenance required the water surface level (Reduced Level, RL) at Baruria Transit, Mawa, Tarpasha, and Sureswar stations to be at $10.83 \mathrm{~m} 1.0 \mathrm{~m}, 2.09 \mathrm{~m}$, and $-0.75 \mathrm{~m}$, respectively. The simulation found $1.57 \mathrm{~m}, 0.37 \mathrm{~m}$, $0.30 \mathrm{~m}$, and $0.27 \mathrm{~m}$ monthly minimum water surface levels at Baruria Transit, Mawa, Tarpasha, and Sureswar stations. Conversely, the frequency analysis showed $1.30 \mathrm{~m}, 0.80 \mathrm{~m}, 0.51 \mathrm{~m}$, and 0.11 
m water surface level, respectively, in a 100-year return period. These analytical techniques also discovered that the lowest water levels occurred between December and April each year.

Therefore, Baruria Transit to Tarpasha is unsuitable for the easy movement, migration, and pre-breeding congregation of the Hilsha Fish, while Sureswar station is suitable for breeding. The December to April period was also revealed a difficult time for the movement of Hilsha Fish in the Padma River.

Generally, Padma River plays an essential role in supplying domestic water to Dhaka city through the Padma Jashaldia Water Treatment Plant, which currently has the highest capacity (450 MLD) in Bangladesh and an intake channel close to Station RMP3 (Mawa SW93.5L). Subsequently, the simulated result found that the minimum water surface level was $0.37 \mathrm{~m}$ in March 2019, while the frequency analysis showed a minimum water level of $0.80 \mathrm{~m}$ in the 100 -year return period. The simulated minimum flow was recorded at $3789 \mathrm{~m}^{3} / \mathrm{s}$, and frequency analysis showed a minimum flow of $1992 \mathrm{~m}^{3} / \mathrm{s}$ at Mawa.

\section{DISCLAIMER}

The authors declare no conflict of interest.

\section{AVAILABILITY OF DATA AND MATERIALS}

All data are available from the author

\section{AUTHOR CONTRIBUTION STATEMENTS}

Md. Abu S. developed the numerical and analytical model set up under the supervision of Aysha A. Both the authors made a substantial contribution in discussing the result and drafting the manuscript.

\section{ACKNOWLEDGMENTS}

The author is grateful to the Department of Civil Engineering, Chittagong University of Engineering and Technology (CUET) in Bangladesh, for providing the funds for the acquisition of a Master's of Science degree. The author is also grateful to BWDB for providing hydrological and hydraulic data during the study.

\section{REFERENCES}

Abramowitz, M. and Stegun, I.A., 1965. Handbook of mathematical functions. New York: Dover.

Ahsan, D.A., Naser, M.N., Bhaumik, U., Hazra, S. and Bhattacharya, S.B., 2014. Migration, Spawning Patterns and Conservation of Hilsa Shad (Tenualosa ilisha) in Bangladesh and India.

Akter, A. and Ali, M.H., 2012. Environmental flow requirements assessment in the Halda River, Bangladesh. Hydrological Sciences Journal.

Akter, A. and Tanim, A.H., 2018. A modeling approach to establish environmental flow threshold in ungauged semidiurnal tidal river. Journal of Hydrology, [online] 558, pp.442-459. Available at: <https://doi.org/10.1016/j.jhydrol.2018.01.061>.

Akter, J., 2010. Environmental flow assessment for the Ganges river. (March), p.158.

Arthington, A.H. and Zalucki, J.M., 1998. Comparative evaluation of environmental flow assessment techniques: Review of methods. LWRRDC Occasional Paper Series 27/98.

Baten, M.A. and Titumir, R.A.M., 2016. Environmental challenges of trans-boundary water resources management: the case of Bangladesh. Sustainable Water Resources Management, 2(1), pp.13-27.

Brunner, G.W. and CEIWR-HEC, 2016. HEC-RAS River Analysis System User's Manual. US Army Corps of Engineers-Hydrologic Engineering Center. [online] (January), pp.1-790. Available at: $<$ https://www.hec.usace.army.mil/software/hecras/documentation/HEC-RAS 5.0 Users Manual.pdf $>$.

Editor Engr Taqsem Khan, C.A., Editor, E. and Shahid Uddin Director, A., 2019. DEWASA Annual Report 2018-19.

Ferdows, M., and Hossain, M, 2005. Flood frequency Analysis at Different Rivers in Bangladesh: A Comparison Study on Probability Distribution Functions. Thammasat International Journal of Science and Technology, 10 (3), pp.53- 
62.

Islam, N., 2006. IRLP or the Ecological Approach to Rivers? Economic and Political Weekly, [online] 41(17), pp.1693-1702. Available at: <http://www.jstor.org/stable/4418148>.

Jahid, S.A., 2016. Assessing Environmental Flow for the Kobadak River and Developing a Framework for Its Maintenance Assessing Environmental Flow for the Kobadak River and Developing a Framework for Its Maintenance. (February).

Kite, G.W., 1977. Frequency and risk analysis in hydrology. Fort Collins, CO: Water Resources Publications.

Moly, S.H., Rahman, M.A.T.M. and Saadat, A.H.M., 2015. Environmental Flow Characteristics of the Gorai River, Bangladesh. International Journal of Scientific Research in Environmental Sciences.

Mullick, M., Babel, M. and Perret, S., 2010. Flow characteristics and environmental flow requirements for the Teesta River, Bangladesh. Proceedings of International Conference on ..., [online] pp.105-114. Available at: <http://scholar.google.co.in/scholar?q=mullick +2 $010+$ teesta $\& b t n G=\& h l=e n \& a s \_s d t=0 \% 2 C 5 \# 0>$.

Neill, C., Hotopp, D. and Hunter, B., 2013. Some hydrotechnical features of Padma River, Bangladesh. pp.1-11.

Pusey, B.J. and Arthington, A.H., 1991. The utility and applicability of the in-stream flow incremental methodology (IFIM) for Australian lotic environments. SIL Proceedings, 1922-2010.

Pusey, B.J., Arthington, A.H. and Read, M.G., 1993. Spatial and temporal variation in fish assemblage structure in the Mary River, southeastern Queensland: the influence of habitat structure. Environmental Biology of Fishes.

Rahman, A., Roy C., Rahman, A., Jamil, F., and Islam, M.S., 2019. Environmental Flow
Assessment for the Main Rivers of the NorthWest Zone of Bangladesh. North American Academic Research, 2 (3), pp 81-101.

Rahman, M.A.T.M.T., Moly, S.H. and Saadat, A.H.M., 2013. Environmental Flow Requirement and Comparative Study of the Turag River, Bangladesh. International Journal of Scientific Research in Environmental Sciences.

Rahman, M.K., Akhter, J.N., Nima, A., Ahmed, S.U. and Mazid, M.A., 2003. Studies on geomorphology, ecology and fish production of the 92 rivers of Rajshahi Division, Bangladesh. Bangladesh ]. Fish. Res., 7(2), pp.141-150.

Saha, P.P., 2007. As assesssment of instream flow requirement of Gorai river considering salinity intrusion and fish habitat.

Smakhtin, V., Revenga, C. and Döll, P., 2004. Taking into Account Environmental Water Requirements in Global-scale Water Resources Assessments. Comprehensive Asessment of Water Management in Agriculture Research Report 2. IWMI, Colombo, Sri Lanka. Assessment.

Sultana, R. and Alam, S., 2016. HAZARD CHARACTERISTICS OF NATURAL FLOOD: A CASE STUDY OF PADMA RIVER. 4(12), pp.13-20.

Sunny, A.R., Ahamed, G.S., Mithun, M.H., Islam, M.A., Das, B., Rahman, A., Rahman, T., Hasan, N. and Chowdhury, M.A., 2003. Livelihood Status of the Hilsa ( Tenualosa ilisha ) Fishers : The Case of Coastal Fishing Community of the Padma River, Bangladesh. Journal of Coastal Zone Management, 22(2), p.469.

Tharme, R.E., 2003. A global perspective on environmental flow assessment: Emerging trends in the development and application of environmental flow methodologies for rivers. River Research and Applications.

USGS, 2019. Guidelines for Determining Flood Flow Frequency Bulletin 17C Book 4, Hydrologic Analysis and Interpretation. [online] Book:, Available at: <https://pubs.usgs.gov/tm/04/b05/tm4b5.pdf>. 